\title{
FURTHER MEASUREMENTS OF PROPELLER FAN CHARACTERISTICS
}

\author{
By P. S. Ballif and H. L. Dryden
}

\section{ABSTRACT}

The characteristics of a 4-blade propeller fan $\&$ feet in diameter operating under conditions approximating those encountered in cooling towers have hee'n determined for comparison with the performance of 2-blade propeller fans, thus establishing experimentally the effect of increasing the number of blades. In addition, the characteristies of a 2-blade fan 9 feet 11 inches in diameter operating in a duct 10 feet in diameter have been measured for determining the effect of modifying the conditions of installation. Each fan was tested for two conditions of operation-when the fan was operated as a blower, and when the fan was exhausting air from the duct.

The results have been compared with the performance of an 8 -foot, 2-blate propeller fan of approximately the same pitch/dianeter ratio. 'The chief effeet of increasing the number of blades is to reduce the speed of rotation required to meet given conditions. A faired entrance for the blower arrangement improves the performance of the fan.

\section{CONTENTS}

I. Introduction

II. Apparatus

III. Reduction of observations ...

IV. Comparison of performance of 4-blade fan and 2-blade fan ..... 391

V. Effect of entrance condition . . . .

VI. Use of the characteristic curves _.................... 398

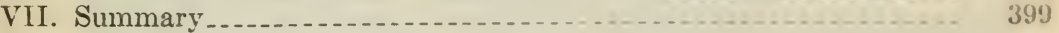

\section{INTRODUCTION}

In an earlier paper ${ }^{1}$ an account has been given of some measurements of the characteristics of seven 2-blade propeller fans as applied to cooling tower installations. It was found that 2-blade propeller fans are suitable for moving large rolumes of air agrinst presisures that are not greatly in excess of 1 inch of water, but for greater pressures the required speed of rotation becomes inconveniently large. It was pointed out that one method of overeoining this difficulty is 10 increase the number of blades.

This report presents the results of an extension of the investigation to the measurement of the characteristics of one 4-blade propeller fan 8 feet in diameter operating under the same conditions as in the previous tests (approximately those encountered in cooling tower installations). The purpose of these measurements was to obtrin data for comparison with the 2-blade fan characteristics as presented in Research Paper No. 193. In addition, the results of some measurements of the characteristics of a 2 -blade propeller fan 9 feet 11 incheo in diameter operating in a duct 10 feet in diameter aro given to illustrate the effect of modifying the conditions of installation. 


\section{APPARATUS}

The equipment and methods of experiment are the same as those described in the preceding paper, except that in the case of the larger fan the inlet ring was removed (fig. 1) and an additional set of measurements was made in which the fan was used as a blower and a faired section was added to the entrance. (Fig. 2.) In the blowing experiments, except for this one series of observations, the entrance was never faired; for the exhaust experiments the entrance was always faired.

The 4-blade fan is 8 feet in diameter and the nominal pitch is 4 feet. The measured geometric pitch is given in Table 1 and the approximate shape and dimensions are shown in Figure 3.

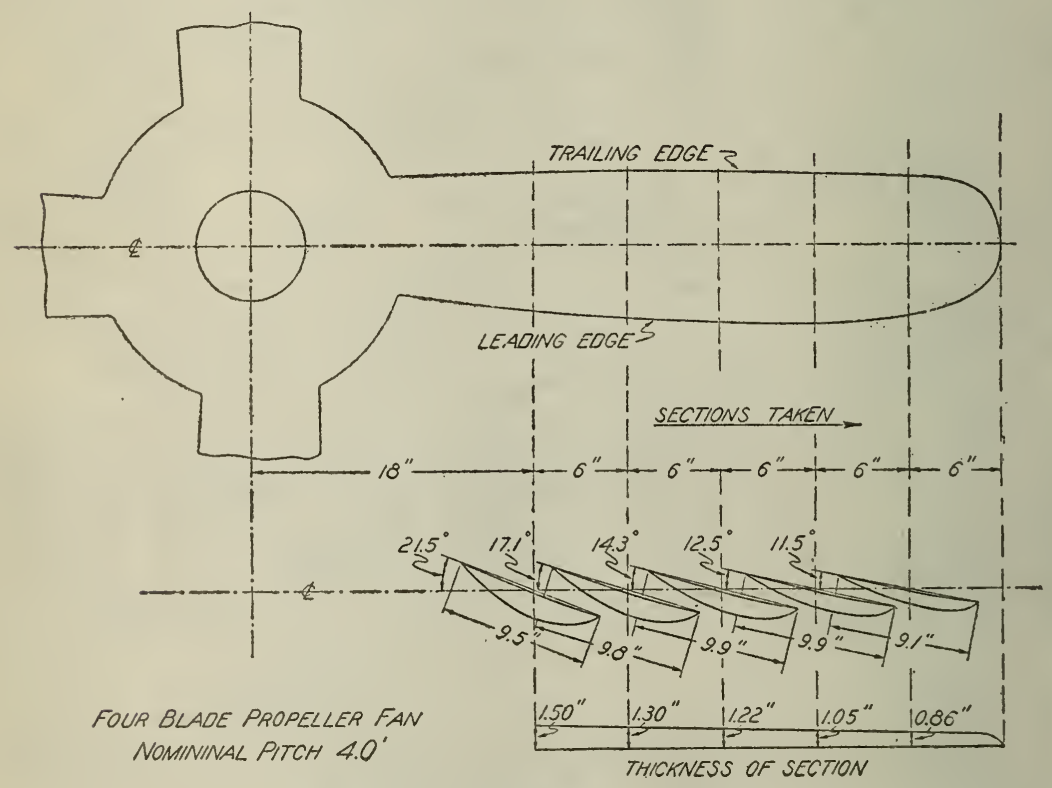

Figure 3

TABLE 1.-Measured pitch of 4-blade fan

Nominal Pitch 4 feet: Radius=distance from axis to point at which pitch is measured

\begin{tabular}{|c|c|c|c|c|c|}
\hline & \multicolumn{5}{|c|}{ Radius (in feet) } \\
\hline & 1.5 & 2.0 & 2.5 & 3.0 & 3.5 \\
\hline $\begin{array}{l}\text { Pitch (in feet) } \\
\text { P'itch/diameter ratio }\end{array}$ & $\begin{array}{l}3.72 \\
.465\end{array}$ & $\begin{array}{l}3.86 \\
.483\end{array}$ & $\begin{array}{l}4.00 \\
.500\end{array}$ & $\begin{array}{l}4.19 \\
.524\end{array}$ & $\begin{array}{l}4.45 \\
.556\end{array}$ \\
\hline
\end{tabular}


B. S. Journal of Research, RP283

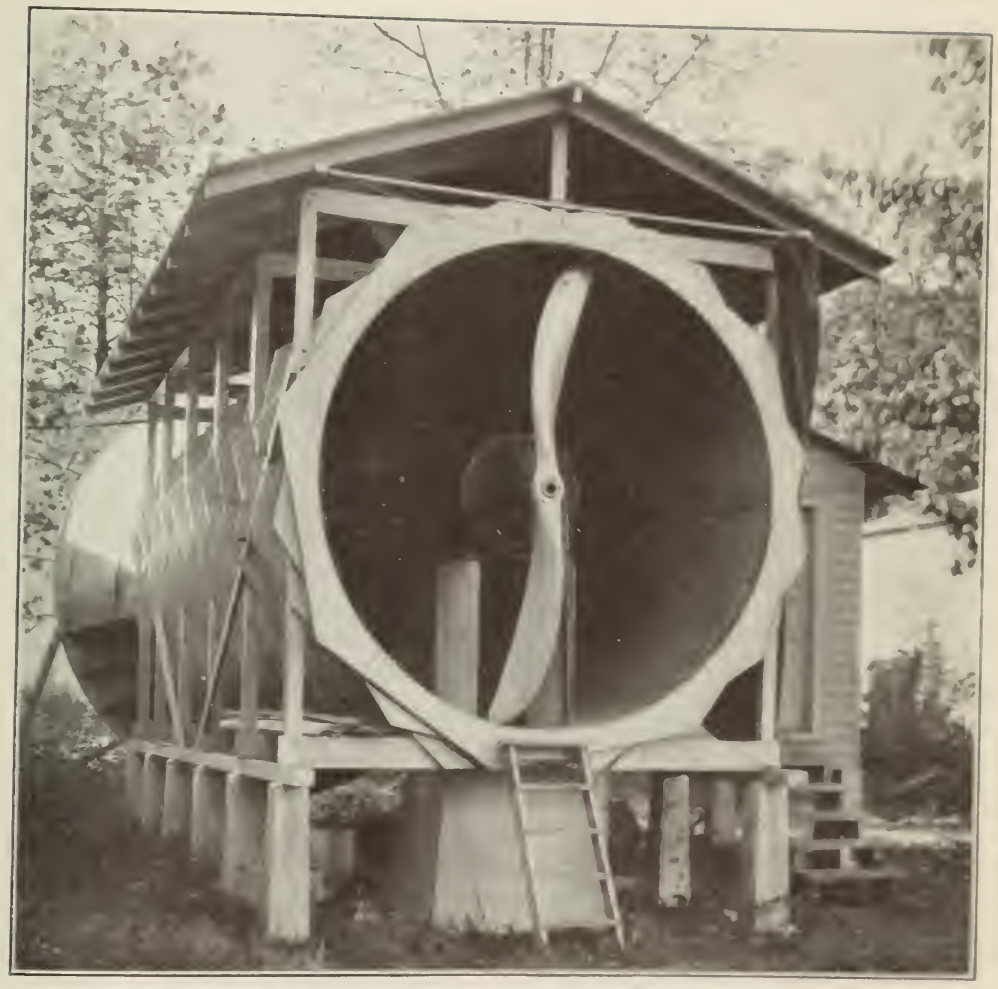

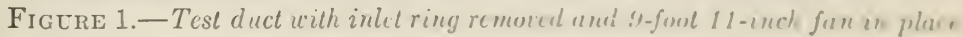


B. S. Journal of Research, RP283

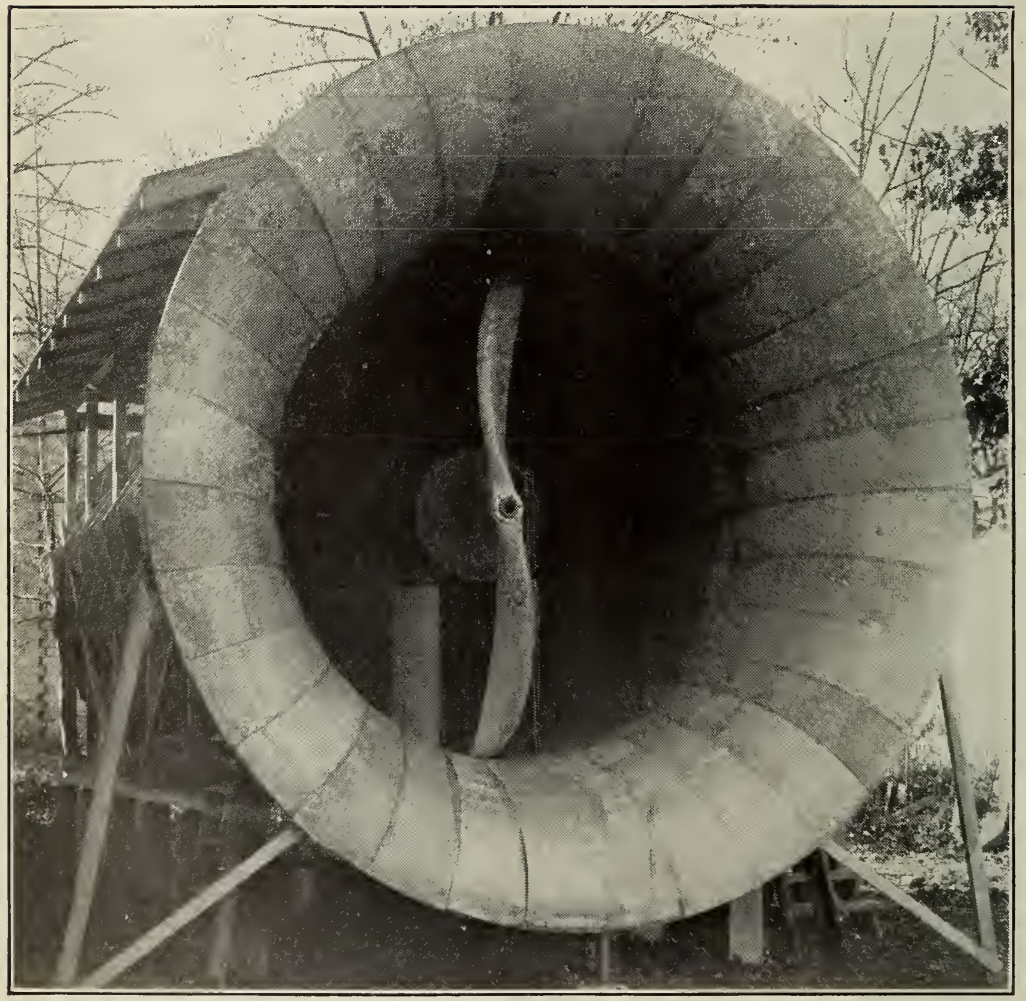

FIGURE 2.- Test duct with faired entrance section for blower condition 
TABLE 2.-Measural pilsh of 2-blude fans

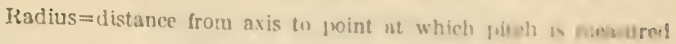

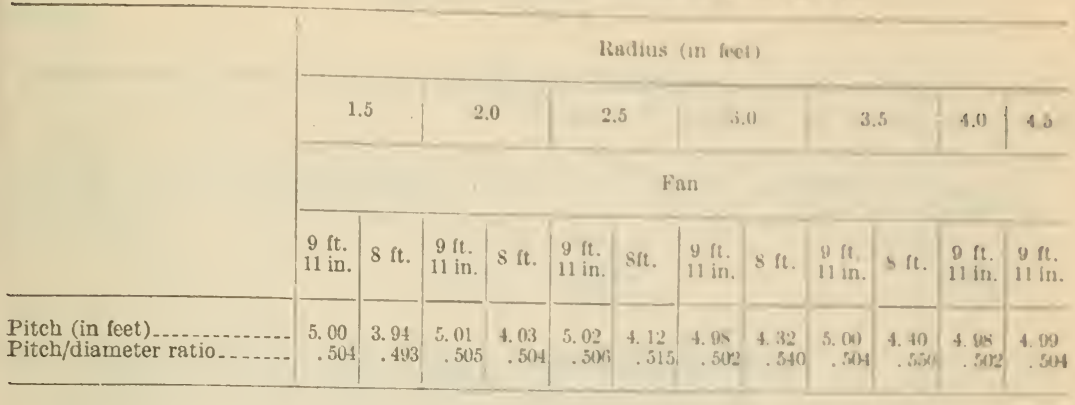

The 2-blade fan (fig. 4) is 9 feet 11 inches in dimmeter and the nominal pitch is 5 feet. The measured angles of the blade sections agreed with the nominal values within $0.1^{\circ}$. The measured geometric pitch is given in Table 2, which includes also, for comparison, data for the previously used S-foot 2-blade fan of approximately the same pitch/diameter ratio. Figure 5 shows the approximate shape and dimensions of the 8-foot fan. All of the fans are constructed of laminated wood.

\section{REDUCTION OF OBSERVATIONS}

To facilitate the estimation of the performance of similar fans when operating under similar conditions, the results are expressed in the form of coefficients defined as follows:

$$
\begin{gathered}
K_{H}=10^{5} \frac{H}{\left.N^{2} I\right)^{2}} \\
K_{Q}=\frac{Q}{N I)^{3}} \\
K_{P}=10^{12} \frac{P}{\left.N^{3} I\right)^{5}} \\
\text { Efficiency }=\frac{5.2 Q H}{33,000 P}=\frac{10^{4} \times 5.2 K_{H} K_{Q}}{33,000 K_{P}}
\end{gathered}
$$

where $K_{H}$ is called the total pressure coefficient, $K_{Q}$ the volume coefficient, $K_{P}$ the power coefficient, and $N=$ rotational speed (r. p.m.), $D=$ diameter of fan (feet), $Q=$ volume of air (cu. ft. min.), $P$-horsepower absorbed by fan, and $H=$ change in total pressure produced by fan (inches of water); that is, the change in static presisure plus the increase (or minus the decrease) in the velocity pressure.

As explained in Research Paper No. 193 the pressure coefficient for the 8 -foot fan operating as a blower is

$$
K_{H}=10^{s} \frac{H_{S}}{N^{2} D^{2}}+4.13 K_{Q^{2}}
$$


and for the exhaust condition

$$
K_{H}=10^{8} \frac{H_{S}}{N^{2} D^{2}}+5.55 K_{Q}^{2}
$$

where $H_{S}$ is the departure of the static pressure in the duct from atmospheric pressure (in inches of water).

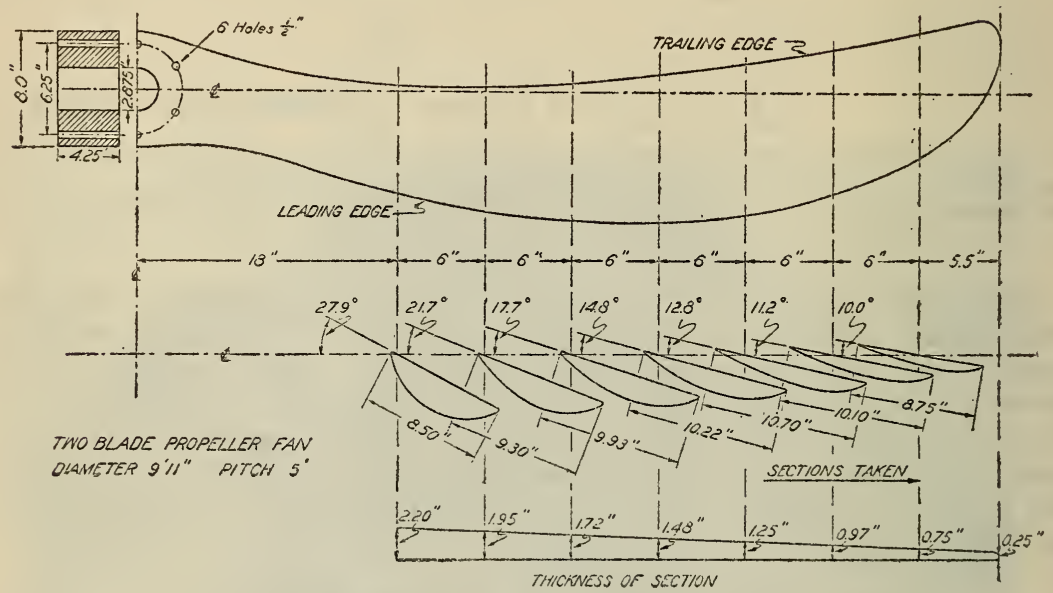

FraURE 4

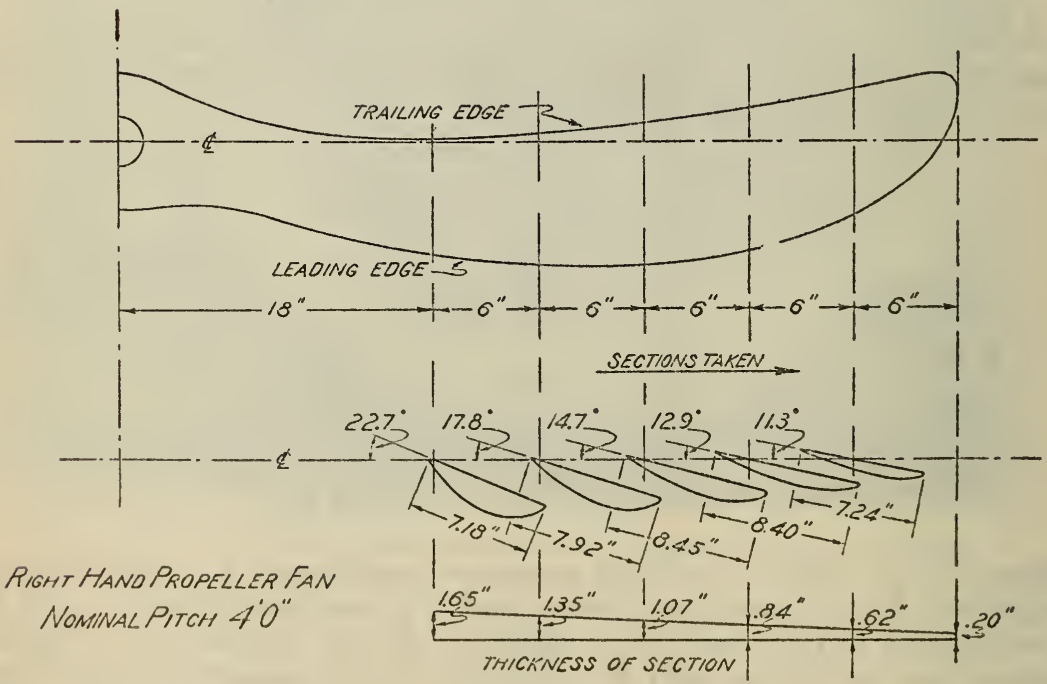

FigURE 5

In the case of the 9-foot 11-inch fan for the blower condition, the air starts from rest at atmospheric pressure, and $H$ is the excess of the total pressure in the 10 -foot duct above that pressure. As $D$ is 9 feet 11 inches, the increase in velocity pressure is

$$
\frac{N^{2} D^{2}}{10^{8}}\left(9.98 K_{Q}^{2}\right)
$$


and

Hence,

$$
H=H_{S}+\frac{N^{2} D^{2}}{10^{3}}\left(9.98 K_{Q}^{2}\right)
$$

$$
K_{H}=10^{8} \frac{H_{S}}{N^{2} D^{2}}+9.98 K_{Q^{2}}^{2}
$$

For the exhaust condition, the discharge velocity is the same as the relocity in the 10 -foot duct, there is no change in the velocity pressure, hence

$$
K_{H}=10^{8} \frac{H_{S}}{\left.N^{2} I\right)^{2}}
$$

\section{COMPARISON OF THE PERFORMANCE OF 4-BLADE FAN AND 2-BLADE FAN}

The results obtained for the 4-blade fan are summarized in 'Tables 3 and 4 and in Figures 6 and 7 . For comparison we have included

\begin{tabular}{|c|c|c|c|c|c|c|c|}
\hline \multicolumn{4}{|c|}{585 r. p. ru. } & \multicolumn{4}{|c|}{700 r. r. m. } \\
\hline$K_{\text {B }}$ & $K_{Q}$ & $I_{P}$ & $\begin{array}{c}\text { Effi- } \\
\text { ciency } 1\end{array}$ & $\kappa_{H}$ & $\mathrm{~F}^{\circ}$ & $K_{p}^{\prime}$ & $\begin{array}{l}\text { EAt:- } \\
\text { ciency } 1\end{array}$ \\
\hline $\begin{array}{l}0.997 \\
\text { 2. } 371 \\
\text { 2. } 787 \\
\text { 3. } 606 \\
\text { 4. } 155 \\
\text { 5. } 640\end{array}$ & $\begin{array}{l}0.3720 \\
.2810 \\
.2405 \\
.1524 \\
.1019 \\
0\end{array}$ & $\begin{array}{l}2.065 \\
2.240 \\
2.185 \\
2.057 \\
1.855 \\
1.729\end{array}$ & $\begin{array}{c}\text { Per cent } \\
27.0 \\
46.5 \\
47.1 \\
42.0 \\
35.7 \\
0\end{array}$ & $\begin{array}{l}0.980 \\
2.357 \\
2.805 \\
3.765 \\
4.162 \\
5.610\end{array}$ & $\begin{array}{l}0.3705 \\
.230 \\
.2385 \\
.1445 \\
.10 \times 3 \\
0^{1}\end{array}$ & $\begin{array}{l}\text { 2. } 122 \\
\text { 2. } 330 \\
\text { 2. } 274 \\
2.08 B \\
1.973 \\
1.510\end{array}$ & $\begin{array}{c}\text { Per cent } \\
27.2 \\
46.0 \\
47.1 \\
41.5 \\
31.3 \\
0\end{array}$ \\
\hline
\end{tabular}

TABLE 3.-4-blade blower fan

Pitch $=4$ leet; pitch/diameter ratio $=0$. in

1 These ralues of efficiency were taken from smoothed curve.

Figures 8 and 9 (taken from Research Paper No. 193) which are the plotted results of the tests on the 2-blade fan of approximately the same pitch/diameter ratio. Table 5 gires the ratio of the characteristics of the two fans at several points. All of the ratios given apply to the particular fans compared. It should especially be noted that these fans differ both in blade outline and in blade area (see figs. 3 and 5), as well as in number of blades.

\begin{tabular}{|c|c|c|c|c|c|c|c|}
\hline \multicolumn{4}{|c|}{585 r. p. m. } & \multicolumn{4}{|c|}{$700 \mathrm{r}$ p. m. } \\
\hline$K_{H}$ & $K_{\theta}$ & $K_{P}$ & $\begin{array}{c}\text { Effi- } \\
\text { ciency }\end{array}$ & $\boldsymbol{K}_{H}$ & $\mathrm{~K}^{\circ}$ & $k_{p}$ & $\begin{array}{c}\text { Ftm. } \\
\text { clency }\end{array}$ \\
\hline $\begin{array}{l}1.233 \\
2.043 \\
2.489 \\
3.308 \\
3.614 \\
4.910\end{array}$ & $\begin{array}{l}0.3005 \\
.2478 \\
.2168 \\
.1545 \\
.1152 \\
0\end{array}$ & $\begin{array}{l}\text { 2. } 115 \\
\text { 2. } 250 \\
2.172 \\
2.0044 \\
1.917 \\
1.554\end{array}$ & $\begin{array}{c}\text { Per cent } \\
27.9 \\
34.4 \\
37.6 \\
39.3 \\
33.5 \\
0\end{array}$ & $\begin{array}{l}\text { 1. } 257 \\
\text { 2. } 017 \\
2.521 \\
3.314 \\
3.626 \\
4 . \times 30\end{array}$ & $\begin{array}{l}0.313 A \\
.24<5 \\
.2125 \\
.1541 \\
.11 \times 0\end{array}$ & $\begin{array}{l}\text { 2. } 257 \\
\text { 2. } 340 \\
2.310 \\
2.044 \\
11063 \\
1.651\end{array}$ & $\begin{array}{c}\text { I'er ee nt } \\
313 \\
34.1 \\
37: 5 \\
395 \\
\text { it } 3 \\
0\end{array}$ \\
\hline
\end{tabular}

TABLE 4.-4-blade cxhraisl fan

Pitch $=4$ fert; pitch/diameter $r 8 t 10=0.50$

1 These values of efficiency were taken from sennothed curve. 


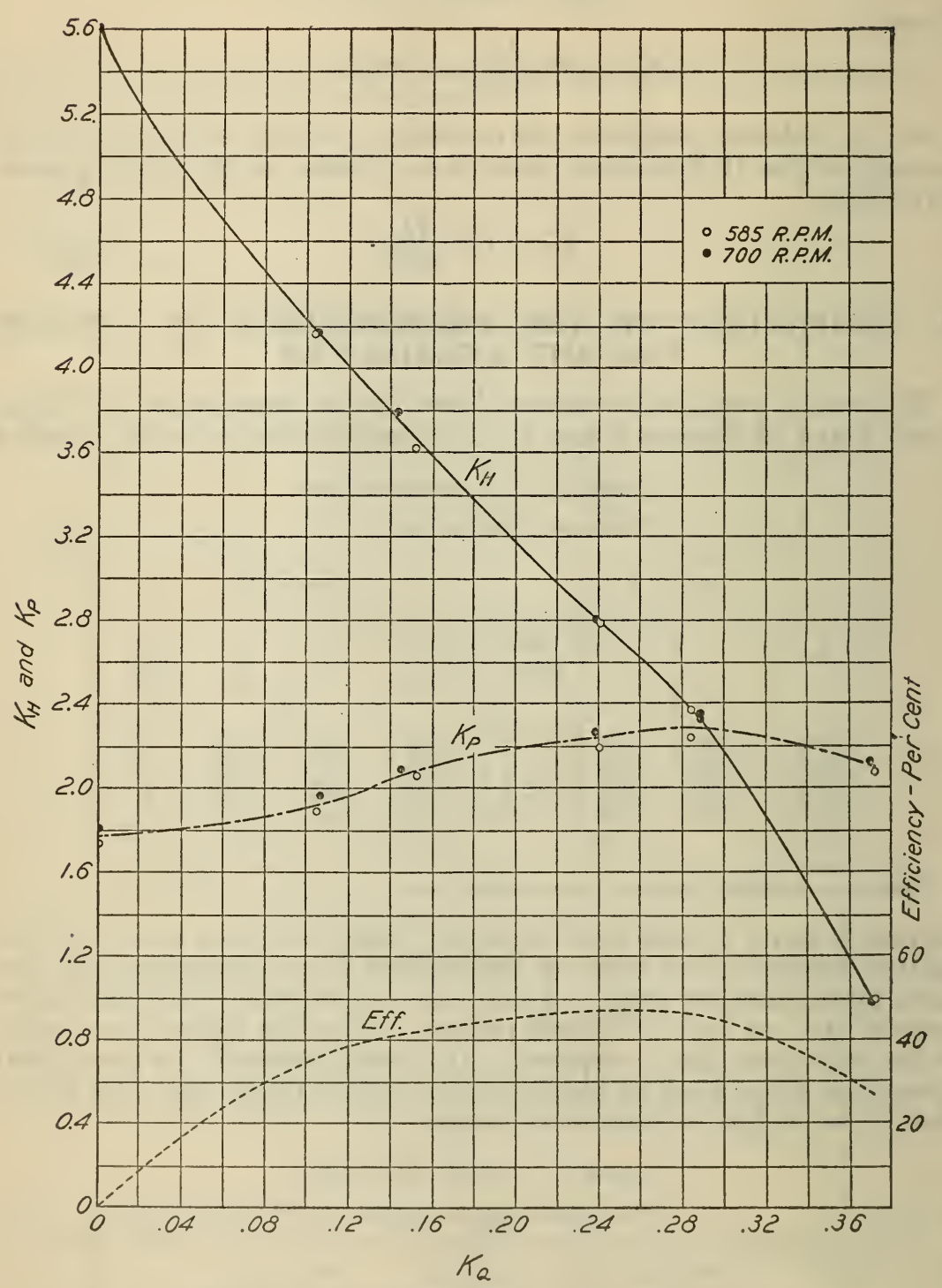

Figure 6.-Characteristics of 4-blade blower fan

Diameter, 8 feet; pitch, 4 feet; pitch/diameter ratio, 0.50 


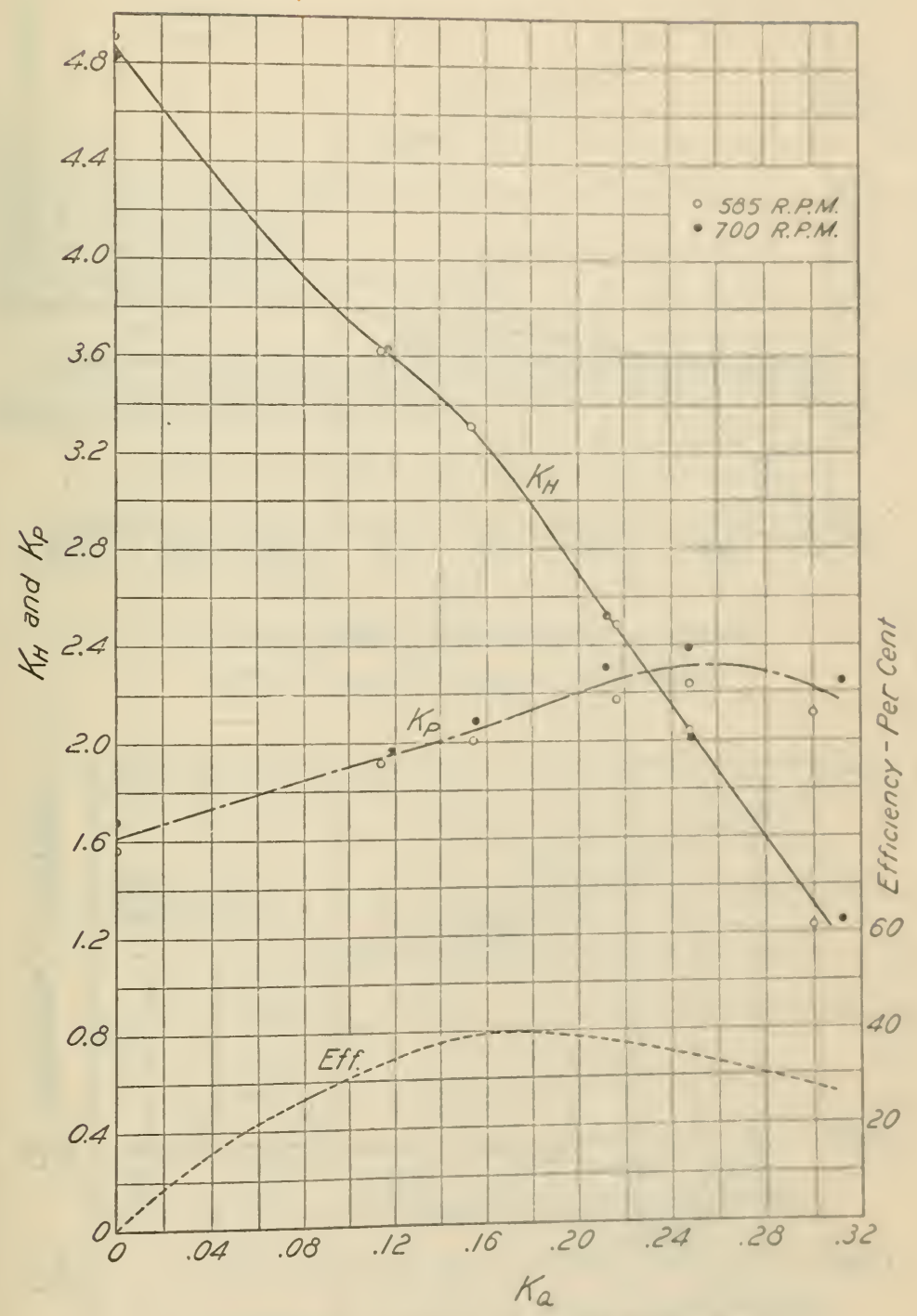

FiguRE 7.-Characteristics of 4-blude exhaust fan

Diameter, 8 feet; pitch, 4 foet; pltch/dlameter ratlo, 0.30 


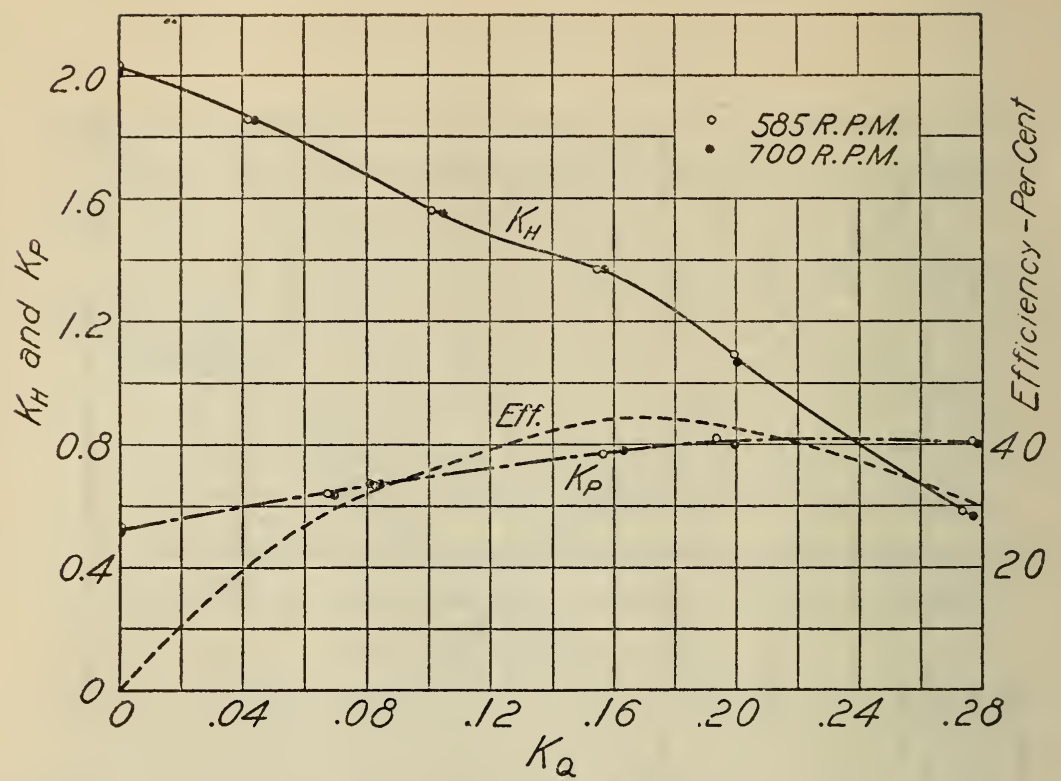

FIGURE 8.-Characteristics of 2-blade blower fan

Diameter, 8 feet; pitch, 4 feet; pitch/dismeter ratio, 0.50

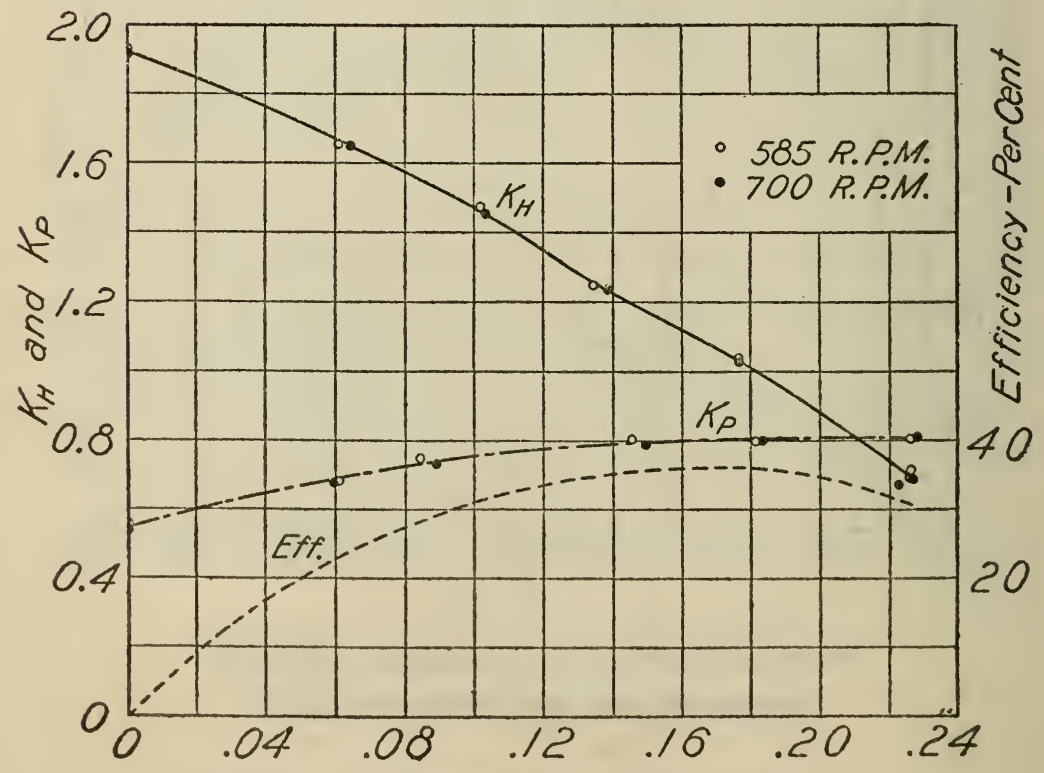

FIGURE 9.-Characteristics of 2-blade exhaust fan

Diameter, 8 feet; pitch, 4 fect; pitch/diameter ratio, 0.50 
TABLE 5. - Ratio of the characteristics of the :-blade fan lot those of the 2-blude fan

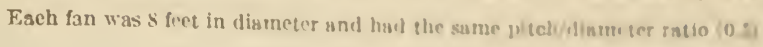

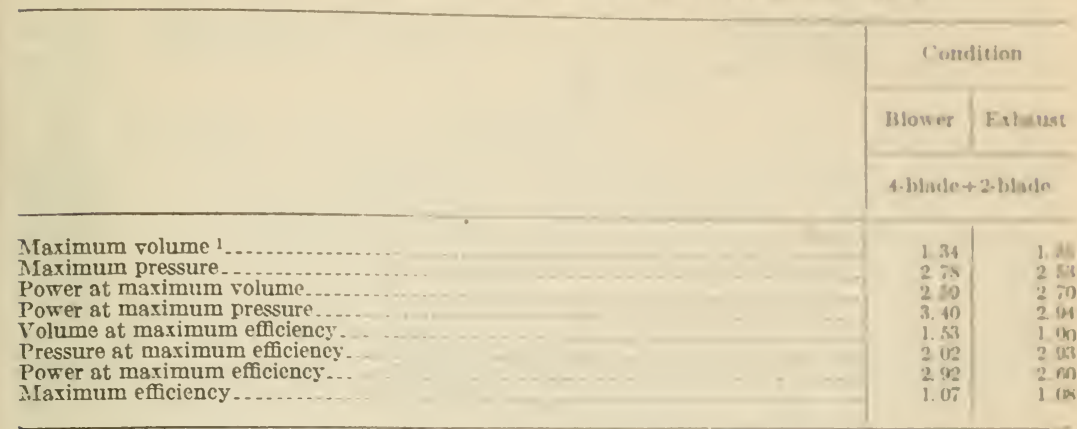

1 The value given for the maximum rolume is that ohtained with resistance in the duct, that cauw.1 by the honeycomb-partition and the motor; hence the values given may lee slfplitly increasud by rufuelng: the duct resistance. It should be noted, however, that the curves ean mot he extralnolated to zero fre". sure, since $H$ includes the pressure due to relocity.

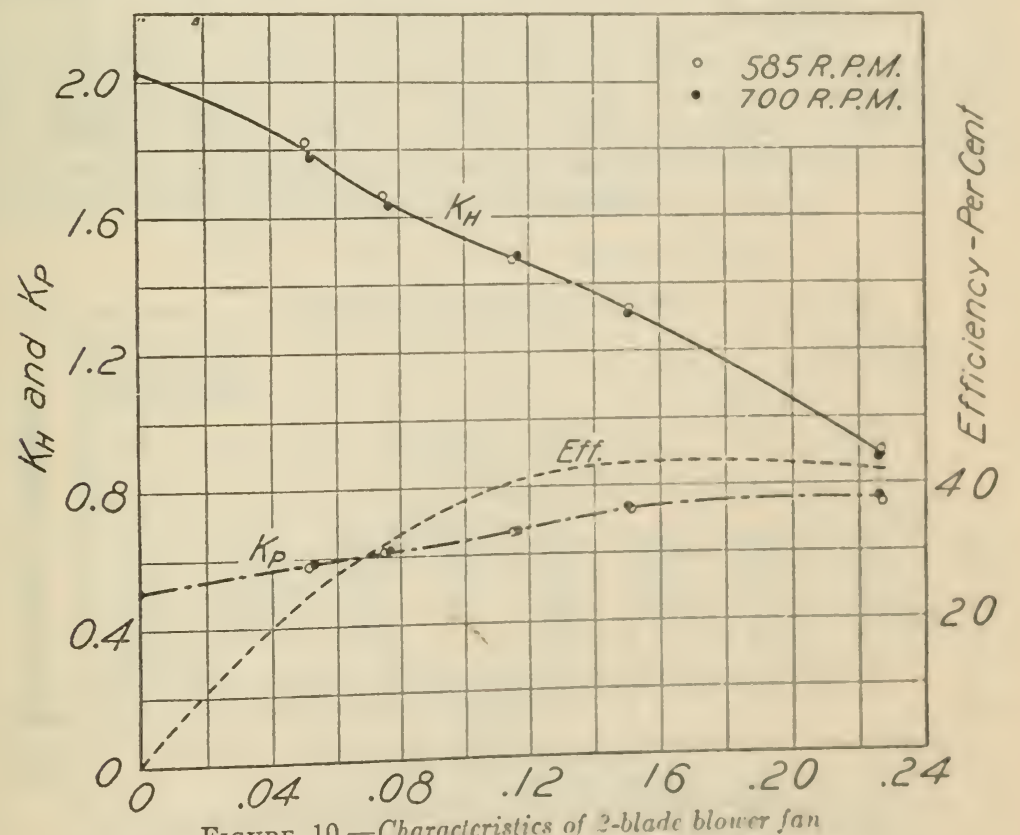

Figure 10.-Charactcristics of 3-blade blouer fan

Diameter, 9 feet 11 inches; pitch, 5 fert; pitch dlimeter ratlo, 0 :A)

\section{EFFECT OF ENTRANCE CONDITION}

The results for the 9-foot 11-inch 2-blade fan are summarized in Tables 6, 7, and 8 and in Figures 10, 11, and 12. On compuring Figure 10 with Figure 8, the two sets of curves are seen to be in fnirly good agreement, the pressure and the power for the 8 -foot fan being 2 or 3 per cent higher throughout most of the range. (On comparing 


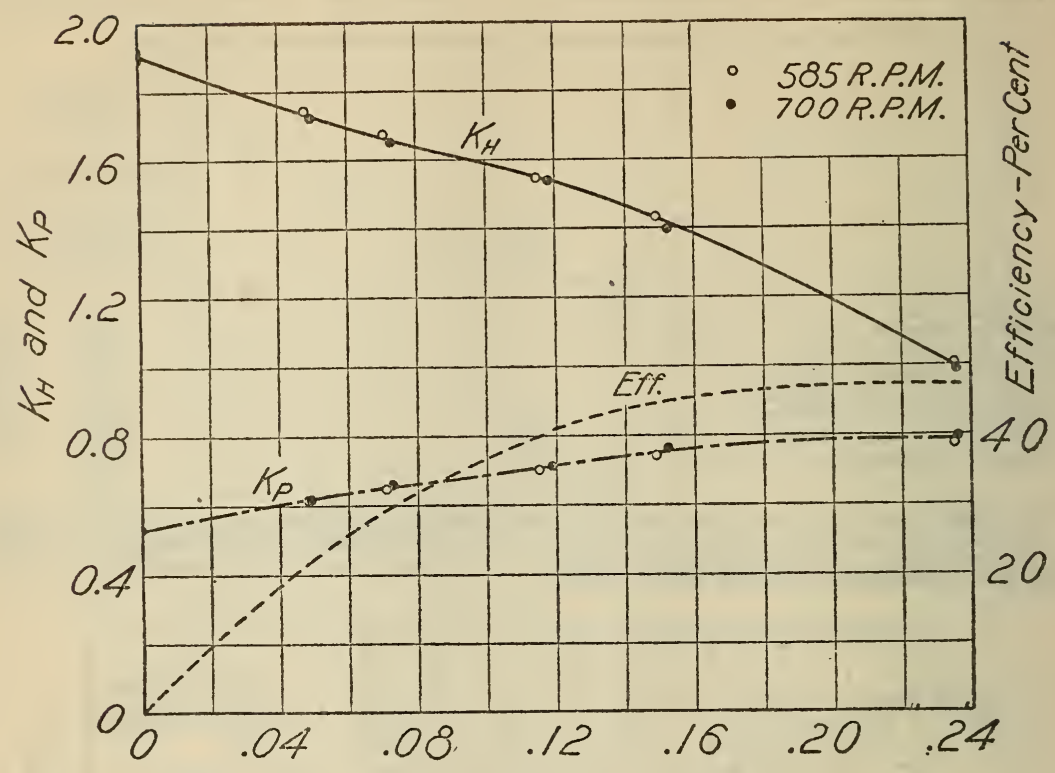

FIGURE 11.-Characteristics of 2-blade exhaust fan

Diameter, 9 feet 11 inches; pitch, 5 feet; pitch/diameter ratio, 0.50

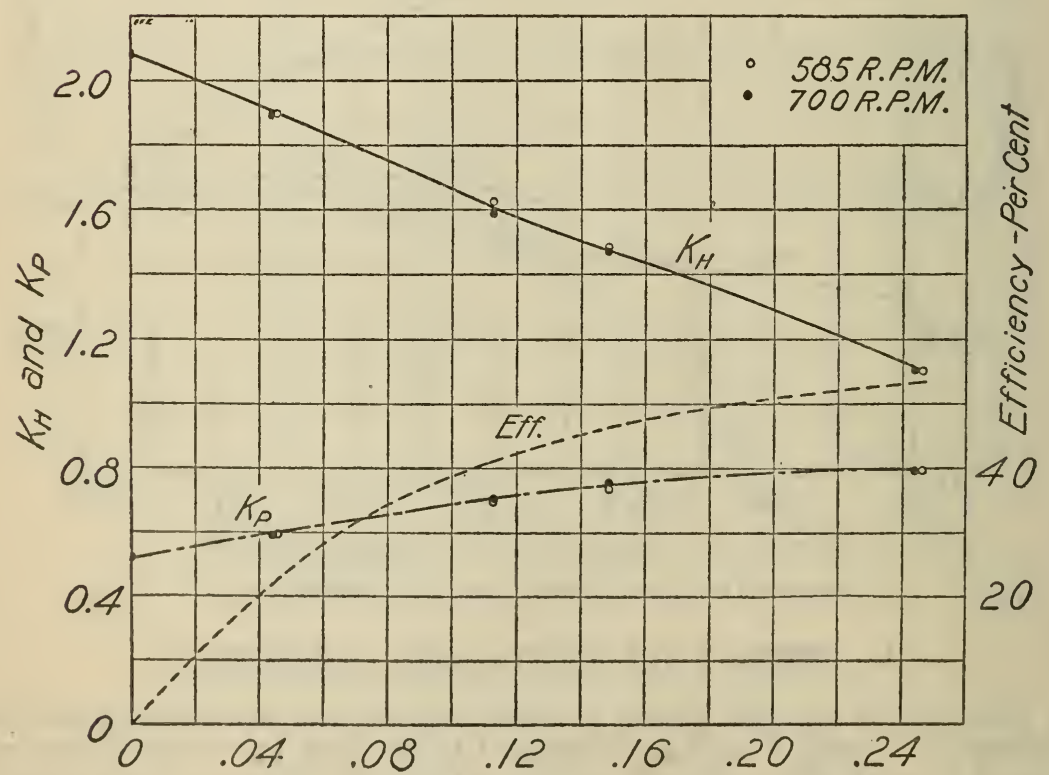

FIGURE 12.-Characteristics of 2-blade blower fan with faired entrance section Diameter, 9 feet 11 inches; pitch, 5 feet; pitch/diameter ratio, 0.50 
Figure 10 with Figure 12, wo see that the chicf effect of the faired entrance section is to increase the value of the pressure coefficient; at maximum volume the increase is about 25 per cent. It also increases the power coefficient by 1 or 2 per cent over most of the range, and the efficiency at maximum rolume from 42 per cent to about 5;3 per cent.

On comparing Figure 11 with Figure 9, it is seen thit, for the exhaust condition, the pressure produced at maximum roime by the 9 -foot 11-inch fan is about 50 per cent greater than thint for thin 8 -foot fan of approximately the same pitch/diameter ratio; the power for the 9-foot 11-inch fan is from 2 to 5 per cent less than for the 8 -foot fan, and the maximum efliciency is increased from 36 per cent to 47 per cent. In the case of the 9 -foot 11 -inch fan there was no inlet ring, and it is our opinion that the increase in efficiency is due to the absence of the inlet ring rather than to tho increase in the diameter of the fan.

From the above comparisons it is readily seen that the entrance and exit conditions have an appreciable effect on the performance of the fans. For a duct 10 feet in diameter, an S-foot fan mounted in an inlet ring to simulate the wall condition in cooling tower applications is nearly as efficient as a fan 9 feet 11 inches in diameter for the blower condition, but is much less efficient for the exhaust condition. The faired entrance section improves the performance when the fan is operating as a blower. No data were obtained for the exhaust condition without the faired entrance section.

TABLE 6.-2-blade blower fan (straight enlrance)

Pitch $=5$ feet $;$ pitch/diameter ratio $=0.50$

\begin{tabular}{|c|c|c|c|c|c|c|c|}
\hline \multicolumn{4}{|c|}{585 r. p. m. } & \multicolumn{4}{|c|}{700 r. p. m. } \\
\hline$K_{H}$ & $K_{Q}$ & $K_{P}$ & $\begin{array}{c}\text { Effi- } \\
\text { cicney } 1\end{array}$ & $K_{H}$ & Io & $K_{P}$ & $\begin{array}{l}\text { En- } \\
\text { cincy }\end{array}$ \\
\hline $\begin{array}{l}0.806 \\
1.325 \\
1.474 \\
1.661 \\
1.821 \\
2.020\end{array}$ & $\begin{array}{l}0.2270 \\
.1510 \\
.1150 \\
.0752 \\
.0512 \\
0\end{array}$ & $\begin{array}{l}0.741 \\
.721 \\
.663 \\
.616 \\
.577 \\
.502\end{array}$ & $\begin{array}{c}\text { Per cent } \\
42.0 \\
43.0 \\
40.2 \\
32.0 \\
24.8 \\
0\end{array}$ & $\begin{array}{l}0.808 \\
1.304 \\
1.4 \times 3 \\
1.634 \\
1.776 \\
2.020\end{array}$ & $\begin{array}{l}0.2260 \\
.1505 \\
.1170 \\
.0770 \\
.0524 \\
0\end{array}$ & $\begin{array}{l}0.763 \\
.734 \\
.687 \\
.618 \\
D 11 \\
.7 A 7\end{array}$ & $\begin{array}{c}\text { Per cent } \\
12.0 \\
43.0 \\
40.5 \\
32.2 \\
25.2 \\
0\end{array}$ \\
\hline
\end{tabular}

1 These ralues of efficiency were taken from smoothed curre.

TABLE 7.-2-blade cxhaust fan

Pitch $=5$ feet; pitcb/dismeter $\mathrm{min}=0.50$

\begin{tabular}{|c|c|c|c|c|c|c|c|}
\hline \multicolumn{4}{|c|}{$58 \mathrm{~s}$. p. m. } & \multicolumn{4}{|c|}{ (x) } \\
\hline$K_{H}$ & Ko & $K_{P}$ & $\begin{array}{c}\text { Emi- } \\
\text { ciency }\end{array}$ & $\mathrm{h}$ H & Ko & hr & $\begin{array}{l}\text { Fifli. } \\
\text { cieniey }\end{array}$ \\
\hline $\begin{array}{l}1.008 \\
1.430 \\
1.548 \\
1.672 \\
.1 .746 \\
1.920\end{array}$ & $\begin{array}{l}0.2352 \\
.1493 \\
.1150 \\
.0712 \\
.0489 \\
0\end{array}$ & $\begin{array}{r}0.773 \\
.739 \\
.699 \\
.641 \\
.610 \\
.530\end{array}$ & $\begin{array}{c}\text { Percent } \\
47.2 \\
44.5 \\
10.0 \\
20.2 \\
22.0 \\
0\end{array}$ & 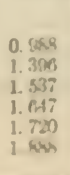 & $\begin{array}{l}0.3200 \\
.150 \\
.1154 \\
.0741 \\
.0134 \\
0\end{array}$ & $\begin{array}{r}0.70 \\
-711 \\
.712 \\
6.1 \\
610 \\
60\end{array}$ & 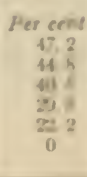 \\
\hline
\end{tabular}

1 These values of efficiency were taken from smootbed curve. 
TABLE 8.-2-blade blower fan (faired cntrance)

Pitch $=5$ feet; pitch/diameter ratio $=0.50$

\begin{tabular}{|c|c|c|c|c|c|c|c|}
\hline \multicolumn{4}{|c|}{585 r. p. m. } & \multicolumn{4}{|c|}{700 r. p. m. } \\
\hline$K_{H}$ & $K_{Q}$ & $K_{P}$ & $\begin{array}{c}\text { Effi- } \\
\text { ciency } 1\end{array}$ & $K_{H}$ & $K_{Q}$ & $K_{P}$ & $\begin{array}{c}\text { Effi- } \\
\text { ciency } 1\end{array}$ \\
\hline $\begin{array}{l}1.101 \\
1.486 \\
1.627 \\
1.899 \\
2.073\end{array}$ & $\begin{array}{l}0.2468 \\
.1490 \\
.1128 \\
.0463 \\
0\end{array}$ & $\begin{array}{r}0.794 \\
.732 \\
.691 \\
.591 \\
.523\end{array}$ & $\begin{array}{c}\text { Per cent } \\
53.2 \\
46.2 \\
41.1 \\
22.9 \\
0\end{array}$ & $\begin{array}{l}1.102 \\
1.471 \\
1.588 \\
1.899 \\
2.090\end{array}$ & $\begin{array}{l}0.2440 \\
.1487 \\
.1127 \\
.0440 \\
0^{-04}\end{array}$ & $\begin{array}{r}0.798 \\
.758 \\
.707 \\
.595 \\
.521\end{array}$ & $\begin{array}{c}\text { Per cent } \\
53.1 \\
46.2 \\
41.1 \\
22.0 \\
0\end{array}$ \\
\hline
\end{tabular}

1 These vaiues of efficiency were taken from smoothed curve.

\section{USE OF THE CHARACTERISTIC CURVES}

The use of the characteristic curves can best be illustrated with an example: Suppose it is desired to have 34,200 cubic feet of air delivered against a total pressure of 0.5 inch of water using a 4 -blade propeller fan of pitch/diameter ratio of 0.50 operating at maximum efficiency. What will be the speed of rotation, the diameter of the fan, and the power required?

From Figure 6 the values of the several coefficients at the point of maximum efficiency are found to be $K_{H}=2.71, K_{Q}=0.25$, and $K_{P}=2.26$.

Combining equations (1),

$$
\begin{aligned}
D^{4} & =\frac{Q^{2} K_{H}}{10^{8} H K_{Q}^{2}} \\
N & =\frac{Q}{D^{3} K_{Q}}
\end{aligned}
$$

Substituting the known values and solving, we get $D=5.64$ feet, and $N=762$ r.p. m.

The pitch is $5.64 \times 0.50=2.82$ feet.

From equations (1)

$$
P=\frac{K_{P} N^{3} D^{5}}{10^{12}}
$$

which gives $P=5.72$ h.p.

In order to compare the above results with the performance of the 2-blade fan of approximately the same pitch/diameter ratio, the same problem may be solved. From Figure 8 the values of the coefficients at maximum efficiency are $K_{Q}=0.17, K_{H}=1.3$, and $K_{P}=0.78$. Substituting these values in equations (2) and solving gives $\mathrm{D}=5.7$ feet, $N=1,087$ r. p. m., and $P=6.04$ h.p. The pitch is $5.7 \times 0.50=2.85$ feet. To get the same performance with the 2-blade fan it is necessary to increase the speed of rotation by about 33 per cent. The power absorbed is 5.6 per cent greater than for the 4-blade fan. 


\section{SUMMARY}

The operating characteristics of a 4-blade fan have been measured under conditions approximating those encountered in cooling towers. The characteristics of a 2-blade fan 9 feet 11 inches in diameter have been measured under more general conditions of operation, and the effect of fairing the entrance has been studied.

The results have been expressed in the form of pressure ard power coefficients plotted against a volume coefficient in such a manner as to facilitate the estimation of the performance of similar funs of any diameter and speed of rotation when operating under similar conditions.

The 4-blade fan shows an increase in the range of pressure and volume coefficients as compared with the 2-blade fan of approximately the same pitch/diameter' ratio. 'The effect of increasing the number of blades is to reduce the speed of rotation required to meet given conditions, and to increase the efficiency to a small extent.

For a duct 10 feet in diameter, an 8 -foot fan mounted in an inlet ring to simulate the wall condition in cooling towers is nearly as efficient as a fan 9 feet 11 inches in diameter for the blower condition, but is much less efficient for the exhaust condition. The faired entrance section for the blower arrangement improves the performance of the fan.

Washington, January $7,1931$. 